\title{
TINGKAT KEBERLANJUTAN LAHAN SAWAH DI KELURAHAN SETIANAGARA, KECAMATAN CIBEUREUM, KOTA TASIKMALAYA, JAWA BARAT
}

\author{
Sustainability Level of Paddy Field in Setianagara, \\ Cibeureum District, Tasikmalaya City, West Java
}

\author{
Anggia Adita Mawarsari ${ }^{*}$, Trisna Insan Noor ${ }^{1}$ \\ ${ }^{1}$ Program Studi Agribisnis, Fakultas Pertanian, Universitas Padjadjaran \\ Email: anggia.adita@gmail.com
}

(Diterima 12-01-2020; Disetujui 20-01-2020)

\begin{abstract}
ABSTRAK
Pembangunan pertanian di Indonesia menghadapi permasalahan sumberdaya lahan yang semakin langka akibat meningkatnya alih fungsi lahan pertanian. Berbagai upaya dilakukan untuk menjaga ketersediaan lahan sawah salah satunya menetapkan kebijakan LP2B (Lahan Pertanian Pangan Berkelanjutan). Salah satu daerah yang termasuk kawasan LP2B yaitu Kelurahan Setianagara, Kecamatan Cibeureum, Kota Tasikmalaya. Penelitian ini bertujuan untuk mengetahui sejauh mana tingkat keberlanjutan lahan sawah dan menganalisis faktor-faktor yang sensitif yang mempengaruhi tingkat keberlanjutan lahan sawah. Desain pada penelitian ini menggunakan desain kuantitatif dengan metode survei. Alat analisis yang digunakan adalah metode Multidimensional Scaling dalam teknik Rap-PaddyField. Hasil analisis menunjukan tingkat keberlanjutan kelima dimensi (sosial, ekonomi, lingkungan, teknologi, serta hukum dan kelembagaan) seluruhnya termasuk dalam kategori kurang berkelanjutan. Indeks keberlanjutan lahan sawah secara multidimensi sebesar 38,69\% dimana termasuk dalam kategori kurang berkelanjutan dengan indeks terendah pada dimensi hukum dan kelembagaan sebesar 29,67\%. Sedangkan faktor-faktor sensitif yang paling mempengaruhi tingkat keberlanjutan lahan sawah secara multidimensi yaitu subsidi, penggunaan benih lokal bersertifikat, dan rasa sayang terhadap lahan. Penelitian ini menunjukan perlu direalisasikannya kebijakan LP2B dengan memperhatikan faktor-faktor sensitif berdasarkan hasil penelitian ini.
\end{abstract}

Kata kunci: Tingkat Keberlanjutan, Mutidimensional Scaling, Alih Fungsi Lahan

\begin{abstract}
Agricultural development in Indonesian faces the problem of land resource scarcity due to the increased conversion of agricultural land. Various attempts were made to maintain the availability of paddy fields, one of them was to establish the LP2B (Sustainable Food Agricultural Land) policy. One of the areas included in the LP2B area is Setianagara, Cibeureum District, Tasikmalaya City. This study aims to determine the sustainability level of paddy fields and analyze sensitive factors in influencing the level of sustainability of paddy fields. The design in this study uses quantitative design and survey methods. The analytical tool used is the Multidimensional Scaling method in the Rap-PaddyField technique. The analysis shows the level of sustainability of the five dimensions (social, economic, environmental, technological, legal and institutional) all included in the less sustainable category. Multidimensional paddy field sustainability index at $38.69 \%$ which is included in the less sustainable category. The sensitive factors or attributes that most influence the level of sustainability of multidimensional paddy fields are subsidies, the use of certified local seeds, and affection for the land. This study shows the need for LP2B policies to be realized by noting into sensitive factors of the results of this study.
\end{abstract}

Keywords: Sustainability Level, Multidimensional Scaling, Land Conversion 


\section{PENDAHULUAN}

Pembangunan pertanian menghadapi berbagai permasalahan salah satunya adalah lebih cepatnya laju permintaan pangan dibandingkan dengan pertumbuhan produksinya. Apabila kondisi tersebut terus berlanjut, dalam jangka panjang Indonesia akan menghadapi masalah kelaparan. Masalah kelaparan merupakan salah satu poin penting dalam Sustainable Development Goals (SDGs) 2030 yang tertuang pada poin kedua yaitu Zero Hunger. Indikator yang dijadikan tolak ukur pencapaian zero hunger adalah ketahanan pangan dan budidaya pertanian yang berkelanjutan.

Padi merupakan komoditas pangan strategis nasional karena merupakan makanan pokok bagi 95\% masyarakat Indonesia. Kebutuhan masyarakat akan beras sangat tinggi, hal ini tercermin dari tingkat konsumsi beras nasional yang mencapai 124,89 kg/kapita/tahun (BPS, 2017). Lebih dari $95 \%$ produksi beras nasional dihasilkan dari lahan sawah (Swastika et al, 2007). Hal tersebut mengimplikasikan pentingnya lahan sawah dalam pemenuhan kebutuhan beras di masyarakat.

Tantangan utama dalam penyediaan pangan dihadapkan pada ketersediaan sumberdaya lahan yang semakin langka.
Kelangkaan tersebut disebabkan semakin meningkatnya konversi lahan pertanian ke non pertanian. Konversi lahan pertanian tidak bisa dielakan seiring bertambahnya jumlah penduduk dan meningkatnya kebutuhan penggunaan lahan non-pertanian seperti halnya industri dan perumahan.

Badan Pusat Statistik (BPS) menyebutkan luas lahan baku sawah secara nasional terus menurun. Tercatat pada tahun 2018 luas lahan baku sawah tersisa 7,1 juta hektar, turun dibanding tahun 2017 yang masih 7,75 juta hektar. Adapun sebanyak 39\% lahan sawah berada di Pulau Jawa. Dari luas tersebut, lahan sawah di Pulau Jawa memproduksi $51,5 \%$ total produksi padi di Indonesia (BPS, 2017). Angka-angka ini menunjukkan tingginya ketergantungan Indonesia terhadap produksi padi dari lahan sawah di Pulau Jawa.

Pada tahun 2016 Jawa Barat menjadi provinsi ketiga dengan jumlah luas lahan baku sawah terbesar setelah Jawa Timur dan Jawa Tengah (BPS, 2016). Namun, hal tersebut diiringi dengan pengurangan luas lahan baku sawah yang juga tinggi. Pengurangan luas lahan baku sawah tertinggi terdapat di Kabupaten Karawang dengan jumlah luas pengurangan lahan sawah dalam 
(Tabel 1).

Tabel 1.Perkembangan Luas Lahan Baku Sawah Menurut Kabupaten/Kota di Jawa Barat Tahun 2014-2016 (Ha)

\begin{tabular}{clcccc}
\hline No & Kota/Kabupaten & $\mathbf{2 0 1 4}$ & $\mathbf{2 0 1 5}$ & $\mathbf{2 0 1 6}$ & $\begin{array}{c}\text { Perkembangan } \\
\text { Luas Lahan }\end{array}$ \\
\hline 1 & Kab. Indramayu & 115.913 & 115.555 & 115.833 & -80 \\
2 & Kab. Karawang & 97.529 & 96.428 & 95.876 & -1.650 \\
3 & Kab. Sukabumi & 63.986 & 66.692 & 66.579 & 2.593 \\
4 & Kota Tasikmalaya & 5.986 & 5.947 & 5.904 & -82 \\
5 & Kota Banjar & 3.318 & 3.318 & 3.313 & -5 \\
6 & Kota Sukabumi & 1.532 & 1.486 & 1.464 & -68 \\
\hline
\end{tabular}

Sumber: BPS 2017, data diolah

Ketahanan pangan dapat dicapai dengan pengembangan konsep pertanian berkelanjutan (sustainable agriculture). Berbagai upaya untuk mengatasi masalah ketersediaan pangan telah dilakukan, salah satu upaya pemerintah dalam pengendalian alih fungsi lahan demi menjaga ketahanan pangan adalah dengan ditetapkannya UU No.41 Tahun 2009 tentang perlindungan Lahan Pertanian Pangan Berkelanjutan (LP2B), yaitu wilayah budidaya pertanian terutama pada wilayah pedesaan yang memiliki hamparan lahan pertanian pangan berkelanjutan serta unsur penunjangnya dengan fungsi utama untuk mendukung kemandirian, ketahanan, dan kedaulatan pangan nasional.

Kota Tasikmalaya merupakan salah satu kota di Jawa Barat yang sudah menetapkan kebijakan perlindungan Lahan Pertanian Pangan Berkelanjutan (LP2B) yang diatur dalam Peraturan
Daerah Nomor 4 Tahun 2012 paragraf 7 pasal 49 ayat 2 dan terintegrasi dengan Rencana Tata Ruang Wilayah (RTRW) Tahun 2011-2031. LP2B ini diperuntukan untuk empat kecamatan yaitu Purbaratu, Cibeureum, Mangkubumi, dan Kawalu yang meliputi 492 hektar.

Kecamatan Cibeureum merupakan salah satu kecamatan yang termasuk dalam LP2B. Idealnya, setelah ditetapkannya kebijakan LP2B di Kota Tasikmalaya, pengurangan lahan yang terjadi seharusnya berkurang. Namun, dalam kurun waktu 2013-2016 telah terjadi konversi lahan yang merupakan Lahan Pertanian Pangan Berkelanjutan (LP2B) sebesar 5 hektar (Tabel 2). Alih fungsi tersebut disebabkan karena keterdekatan Kecamatan Cibeureum dengan pusat kota serta adanya rencana Kecamatan Cibeureum menjadi pusat pendidikan Kota Tasikmalaya dan pembangunan infrastruktur. 
Tabel 2. Perkembangan Luas Lahan Baku Sawah di 4 Kecamatan Kota Tasikmalaya Tahun 20132016 (Ha)

\begin{tabular}{clccccc}
\hline No & Kecamatan & $\mathbf{2 0 1 3}$ & $\mathbf{2 0 1 4}$ & $\mathbf{2 0 1 5}$ & $\mathbf{2 0 1 6}$ & Luas Konversi \\
\hline 1 & Kawalu & 1.244 & 1.244 & 1.244 & 1.244 & - \\
$\mathbf{2}$ & Cibeureum & $\mathbf{7 6 3 , 5}$ & $\mathbf{7 6 3 , 5}$ & $\mathbf{6 3 , 5}$ & $\mathbf{7 5 8 , 5}$ & $\mathbf{5}$ \\
3 & Mangkubumi & 1.134 & 1.134 & 1.134 & 1.132 & 2 \\
4 & Purbaratu & 499 & 499 & 499 & 494 & 5 \\
\hline & Jumlah & 3604,5 & 3604,5 & 3604,5 & 3633,5 & 12 \\
\hline
\end{tabular}

Sumber: Dinas Pertanian Kota Tasikmalaya, 2017

Kelurahan Setianagara adalah salah satu wilayah di Kecamatan Cibeureum serta termasuk sebagai kawasan LP2B yang memiliki jarak yang cukup dekat ke pusat Kota Tasikmalaya yaitu $\pm 5 \mathrm{~km}$. Wilayah kelurahan yang cukup dekat dengan pusat kota dikhawatirkan dapat memicu peningkatan laju alih fungsi lahan sawah di kawasan LP2B. Dengan demikian, penelitian ini bertujuan untuk mengetahui sejauh mana tingkat keberlanjutan lahan sawah dan menganalisis faktor-faktor yang mempengaruhi keberlanjutan lahan sawah di Kelurahan Setianagara, Kecamatan Cibeureum, Kota Tasikmalaya.

\section{METODE PENELITIAN}

Penelitian ini menggunakan desain kuantitatif deskriptif. Metode penelitian yang digunakan adalah metode survei. Penelitian ini dilakukan dengan menggali data dan fakta yang ada di lapangan selain itu juga keterangan - keterangan faktual di lokasi penelitian. Objek yang diteliti dalam penelitian ini adalah tingkat keberlanjutan lahan sawah. Tempat peneltian ini berlokasi di Kelurahan Setianagara, Kecamatan Cibeureum, Kota Tasikmalaya, Jawa Barat. Penentuan tempat penelitian ini dilakukan secara sengaja (purposive) baik dalam penentuan kota, kecamatan, maupun kelurahan.

Teknik pengambilan sampel dalam penelitian ini menggunakan teknik probability sampling yaitu simple random sampling. Populasi yang digunakan dalam penelitian ini adalah petani pemilik sekaligus penggarap lahan sawah yang termasuk dalam kawasan LP2B di Kelurahan Setianagara. Jumlah sampel petani padi sawah di Kelurahan Setianagara sebanyak 51 orang, data didapatkan dari 104 petani pemilik sekaligus penggarap.

Data dalam penelitian ini bersumber dari data primer dan data sekunder. Alat analisis yang digunakan dalam penelitian ini adalah analisis multidimensional scaling menggunakan 
teknik Rap-PaddyField yang merupakan modifikasi dari Rapfish, yaitu sebuah teknik yang digunakan untuk menilai status keberlanjutan perikanan berbasis metode multidimensional scaling. Atribut-atribut yang digunakan untuk menilai tingkat keberlanjutan diturunkan dari referensi mengenai pembangunan pedesaan (UNDP, 2006; FAO, 2011) dan penelitian terdahulu yang disesuaikan dengan kondisi di lokasi penelitian. Atribut ini dikelompokan berdasarkan kriteria "baik" atau "buruk" yang mengacu pada konsep dari Fisheries Center (2002) yang kemudian di ordinasikan menggunakan metode MDS. Output dari hasil analisis ini berupa indeks keberlanjutan lahan sawah baik dari kelima dimensi (sosial, ekonomi, lingkungan, teknologi, hukum dan kelembagaan) maupun secara multidimensi yang ditunjukan dalam bentuk skor dengan skala 0-100. Indeks keberlanjutan diperoleh dari teknik ordinasi (penentuan jarak) dalam MDS, yang didasarkan pada Euclidian Distance dengan formulasi sebagai berikut:

$d=\sqrt{\left(\left|x_{1}-x_{2}\right|^{2}+\left|y_{1}-y_{2}\right|^{2}+\left|z_{1}-z\right|^{2}\right)+\cdots}$

Hasil lain dari analisis MDS adalah nilai S-Stress (Standarized Residual Sum of Square) dan koefisien determinasi
$\left(\mathrm{R}^{2}\right)$, dimana keduanya mencerminkan ketepatan (goodness of fit) dalam analisis MDS. Nilai S-Stress yang rendah menunjukan good fit dan yang tinggi menunjukkan sebaliknya (Fauzi dan Anna, 2005). Nilai S-Stress yang kurang dari 0,25 dan $\mathrm{R}^{2}$ mendekati 1 (100\%) menunjukan model yang dianalisis sudah baik (Pitcher,2013). Nilai S-Stress diperoleh dengan meregresikan jarak Euclidian (dij) dari titik i ke titik j dengan titik asal (dij) dengan formulasi:

$$
\mathbf{d i j}=\mathbf{a}+\mathbf{b d i j}+\mathbf{e}
$$

Teknik least squared bergantian yang didasarkan pada akar Euclidian Distance (squared distance) atau disebut algoritma ALSCAL digunakan untuk meregresikan persamaan tersebut (Alder et al, 2000). Metode ini mengoptimalisasi jarak kuadrat terhadap titik asalnya dalam tiga dimensi yang disebut S-stress. Sehingga formulasi nilai S-stress adalah sebagai berikut:

$$
s=\sqrt{\frac{1}{m} \sum_{k=1}^{m}\left[\frac{\sum_{i} \Sigma_{j}\left(d_{i j k}^{2}-o_{i j k}^{2}\right)^{2}}{\sum_{i} \Sigma_{j} o_{i j k}^{4}}\right]}
$$

Selanjutnya dilakukan analisis leverage atau sensitivitas untuk melihat atribut yang paling sensitif yang mempengaruhi besar kecilnya indeks keberlanjutan. Atribut yang sensitif diperoleh dari perubahan ordinasi Root 
Mean Square (RMS) pada skala keberlanjutan. Semakin besar perubahan RMS karena hilangnya atribut tertentu berarti atribut semakin sensitif perannya dalam mempengaruhi tingkat keberlanjutan lahan sawah (Fauzi dan Anna, 2005).

Analisis terakhir yang dilakukan adalah analisis Monte Carlo yang digunakan untuk menduga pengaruh

Analisis tingkat keberlanjutan lahan sawah di Kelurahan Setianagara yang dilakukan dengan teknik RAPPaddyField menghasilkan indeks keberlanjutan yang berbeda pada setiap dimensi. Nilai indeks keberlanjutan untuk dimensi sosial, ekonomi, lingkungan, teknologi, serta hukum dan kelembagaan secara berturut-turut adalah 37,68\%, $48,37 \%, 41,00 \%, 36,74 \%$, dan 29,7\%. Nilai indeks yang bervariasi tersebut diklasifikasikan berdasarkan kategori tingkat keberlanjutan, sehingga kelima dimensi berada pada tingkat kurang berkelanjutan. Secara multidimensi, indeks keberlanjutan lahan sawah di Kelurahan Setianagara adalah sebesar 38,69\% dimana masuk kedalam kategori kurang berkelanjutan. Kurang berkelanjutannya lahan sawah di Kelurahan Setianagara disebabkan karena beberapa atribut pada setiap dimensi kesalahan (galat) pada tingkat kepercayaan 95\%. Nilai indeks Monte Carlo kemudian diperbandingkan dengan nilai indeks MDS. Analisis MDS, analisis leaverage dan analisis Monte Carlo tersebut dilakukan menggunakan software Rapfish 3.1 yang di unduh dari www.Rapfish.org.

\section{HASIL DAN PEMBAHASAN}

belum menunjukkan skor yang baik. Nilai indeks tersebut diperoleh berdasarkan hasil penilaian terhadap 28 atribut yang mencakup kelima dimensi yaitu dimensi sosial (6 atribut), dimensi ekonomi (6 atribut), dimensi lingkungan (6 atribut), dimensi teknologi (4 atribut), dan dimensi hukum dan kelembagaan (6 atribut).

Berdasarkan Tabel 3, dimensi dengan indeks keberlanjutan terendah adalah dimensi Hukum dan Kelembagaan dengan indeks 29,67\%. Sedangkan dimensi dengan indeks keberlanjutan tertinggi adalah dimensi ekonomi dengan nilai 48,47\%. Ordinasi MDS pada tiap atribut dapat dilihat pada Gambar 1. 
Tabel 3 Nilai Indeks MDS Seluruh Dimensi

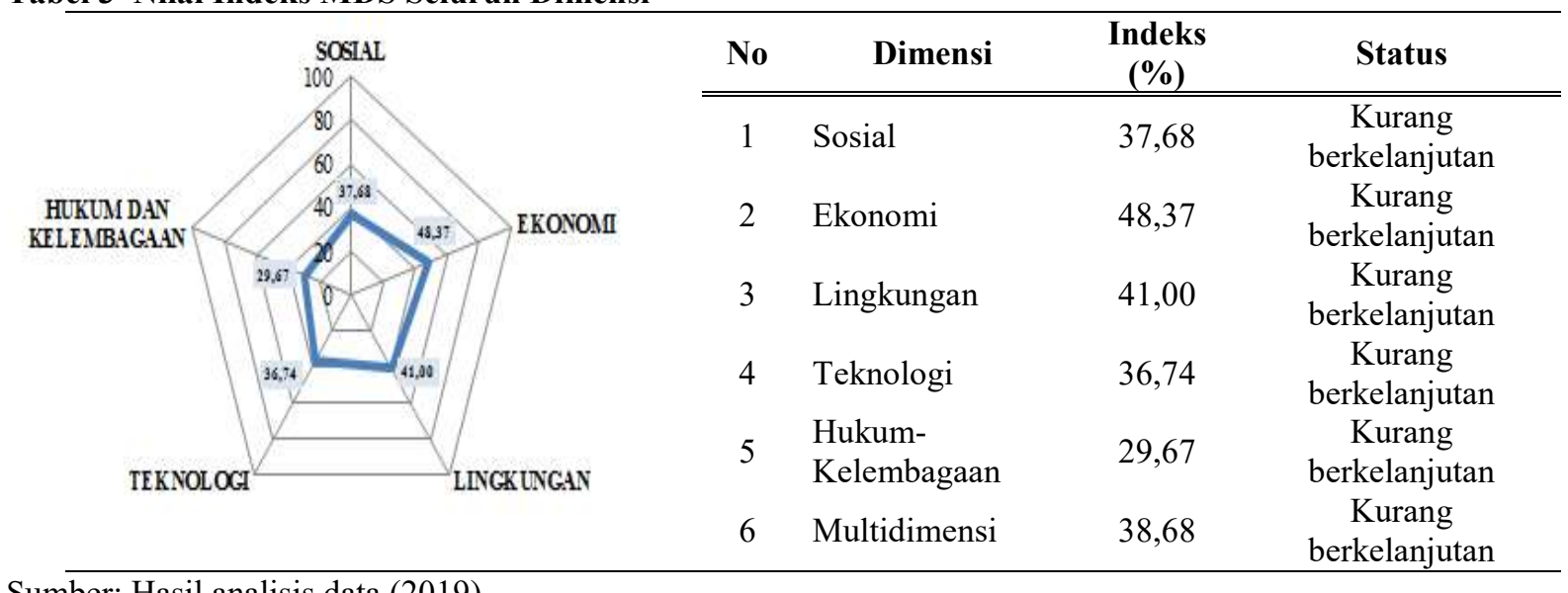

Hasil statistik yang menunjukan ketepatan suatu model (Goodness of Fit) dapat dilihat pada tabel 4. Nilai Stress dalam analisis ini adalah $22,5 \%$ yang didapatkan dari hasil rata-rata nilai stress setiap dimensi dimana nilai tersebut sudah baik karena $\mathrm{S}<25 \%$. Adapun nilai selang kepercayaan $\left(\mathrm{R}^{2}\right)$ dalam analisis ini adalah 92,2\% yang artinya model yang dianalis menggunakan peubahpeubah saat ini sudah menjelaskan $92,2 \%$ dari model yang ada. Nilai stress dan $\mathrm{R}^{2}$ tersebut menunjukan ketepatan atau akurasi setiap dimensi yang dianalisis.

Tabel 4 Nilai Statistik Hasil Analisis MDS

\begin{tabular}{clcccccc}
\hline No & $\begin{array}{l}\text { Atribut } \\
\text { Statistik }\end{array}$ & Sosial & Ekonomi & Lingkungan & Teknologi & Hukum-Kelembagaan & $\begin{array}{c}\text { Rata- } \\
\text { rata }\end{array}$ \\
\hline 1 & Stress & 0.2258 & 0.2402 & 0.2191 & 0.2368 & 0.2049 & 0.225 \\
2 & $\mathrm{R}^{2}$ & 0.9338 & 0.9163 & 0.9366 & 0.9208 & 0.9544 & 0.922 \\
3 & $\begin{array}{l}\text { Jumlah } \\
\text { iterasi }\end{array}$ & 2 & 2 & 2 & 2 & 2 & 2 \\
\hline
\end{tabular}

Sumber: Hasil analisis data (2019)

Analisis selanjutnya yang dilakukan adalah analisis sensitivitas analisis ini menunjukan atribut-atribut yang sensitif dan berpengaruh pada tingkat keberlanjutan lahan sawah di Kelurahan Setianagara. Atribut tersebutlah yang kemudian akan mempengaruhi tinggi rendahnya tingkat keberlanjutan setiap dimensi. Analisis ini dilakukan pada setiap dimensi yang dapat dilihat pada Tabel 4.

\section{Dimensi Sosial}

Pada dimensi sosial (Gambar 1a) dua atribut dengan sensitivitas tertinggi adalah atribut rasa sayang terhadap lahan $(6,53 \%)$ dan regenerasi petani $(4,43 \%)$ Dengan indeks keberlanjutan dimensi 
sosial sebesar $37,68 \%$ dimensi sosial masuk kedalam kategori kurang berkelanjutan. Atribut sensitif yang mempengaruhi dimensi sosial dipengaruhi oleh rasa sayang terhadap lahan yang masih kurang yang ditandai dengan adanya petani yang mempunyai rencana untuk menjual lahannya. Selain itu, regenerasi petani yang sangat buruk

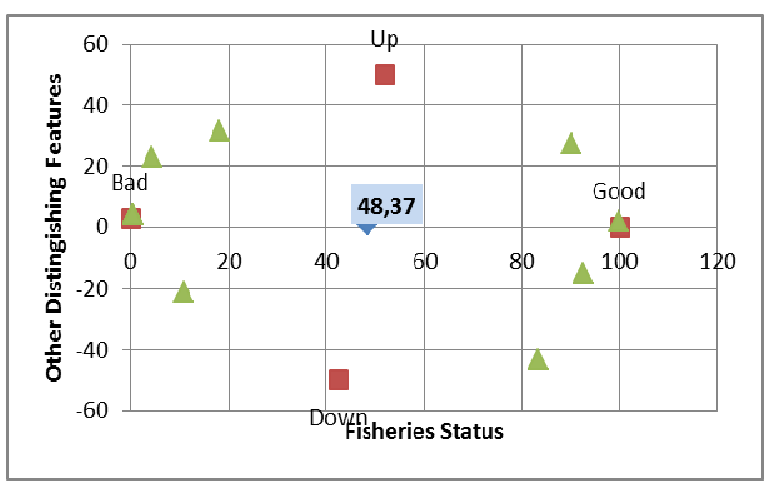

(a) Dimensi Sosial

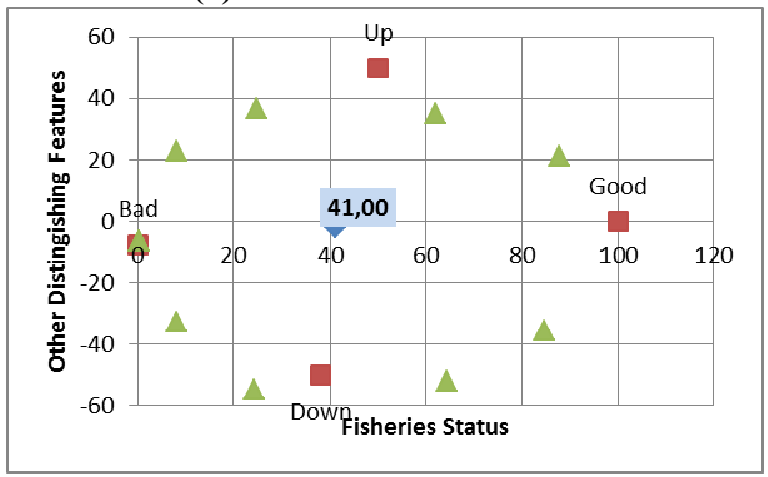

(c) Dimensi Lingkungan juga menyebabkan kurang berkelanjutannya dimensi sosial, rata-rata anak petani tidak bersedia meneruskan kegiatan usahatani milik orangtuanya sehingga anak petani cenderung akan menjual lahan warisan dari orangtuanya atau mengalihfungsikan lahannya untuk kegiatan non-pertanian.

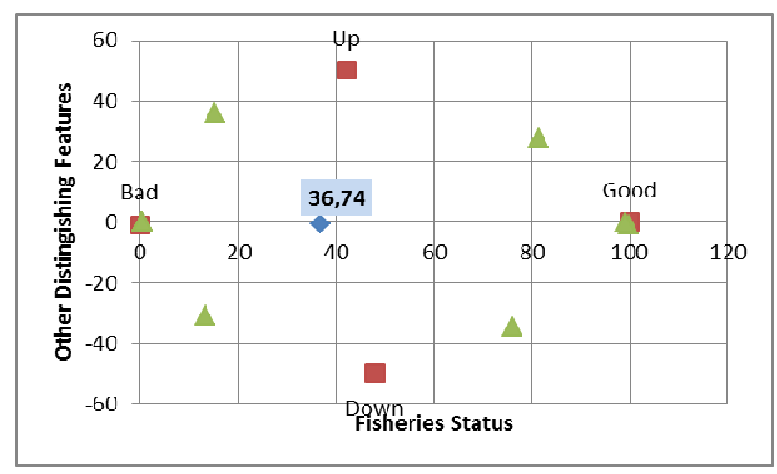

(b) Dimensi Ekonomi

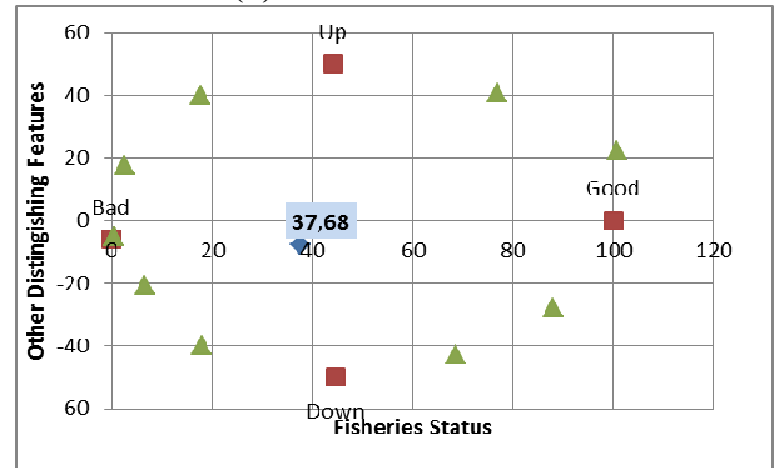

(d) Dimensi Teknologi

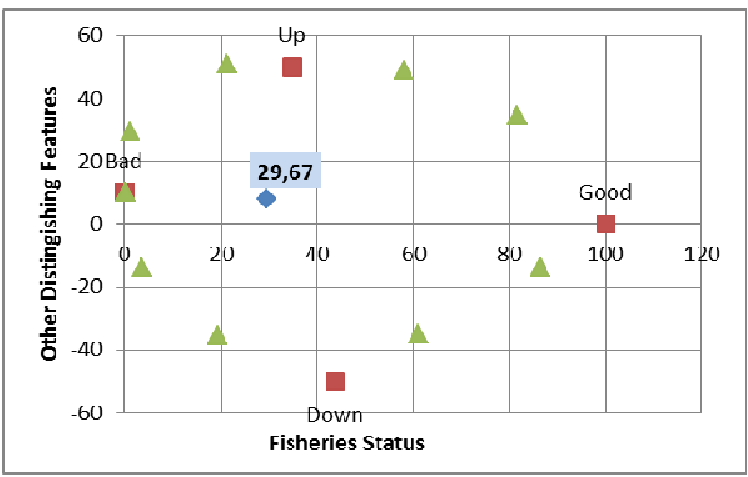

(e)Dimensi Hukum dan Kelembagaan

Gambar 1 Hasil Analisis MDS (Sumber: Hasil analisis data (2019) 


\section{Dimensi Ekonomi}

Pada dimensi ekonomi (Gambar 1b) tiga atriatribut akses penyuluhan yang relatif rendah mbut dengan sensitivitas tertinggi adalah atribut permodalan usahatani dan mekanisme bagi hasil. Meskipun indeks keberlanjutan dimensi ekonomi masih tergolong dalam kategori kurang berkelanjutan (48,7\%), indeks tersebut merupakan yang tertinggi dibandingkan kelima dimensi lainnya. Tingginya indeks keberlanjutan dimensi ekonomi disebabkan relatif tingginya skor yang diberikan pada atribut permodalan usahatani dan kepemilikan peralatan usahatani. Rata-rata petani sudah menggunakan modal sendiri dan memiliki peralatan usahatani sendiri. Meskipun demikian, modal yang dimiliki masih terbatas untuk memperoleh input pokok seperti benih dan pupuk sehingga tidak memungkinkan bagi petani dalam menjangkau teknologi. Selain itu, mekanisme bagi hasil dengan sistem 50\% porsi penggarap dan $50 \%$ porsi pemilik dengan seluruh resiko dibebankan pada penggarap masih dianggap tidak begitu menguntungkan penggarap mengingat mereka merupakan petani kecil yang banyak menanggung risiko produksi dan pemasaran (Rasmikayati dkk., 2017).

\section{Dimensi Lingkungan}

Pada dimensi lingkungan (Gambar 1c) dua atribut dengan sensitivitas tertinggi adalah atribut penggunaan bibit lokal bersertifikat $(8,16 \%)$ dan penggunaan pestisida nabati (5,64\%). Indeks keberlanjutan dimensi lingkungan berada dibawah dimensi ekonomi yaitu sebesar $41,00 \%$. Lebih tingginya indeks keberlanjutan dimensi lingkungan dibanding tiga dimensi lain dibawahnya dikarenakan rata-rata petani sudah menggunakan benih lokal dan bersertifikat. Meskipun demikian, kurang berkelanjutannya dimensi lingkungan disebabkan oleh relatif rendahnya skor yang diberikan untuk atribut penggunaan pestida nabati dan atribut pemanfaatan limbah sawah menjadi pupuk organik. Rata-rata petani masih menggunakan pestisida kimia karena dianggap lebih praktis dan efektif membasmi hama dan penyakit, adapun sebagian petani hanya menjadikan pestisida nabati sebagai selingan atau tambahan dari pestisida kimia. Selain itu pemanfaatan limbah sawah untuk pupuk organik juga masih kurang, rata-rata petani lebih sering membakar limbah sawah. 


\section{Dimensi Teknologi}

Pada dimensi teknologi (Gambar 1d) dua atribut dengan sensitivitas tertinggi adalah atribut ketersediaan teknologi dan adaptasi teknologi. Indeks keberlanjutan dimensi teknologi sebesar $36,74 \%$ yang termasuk dalam kategori kurang berkelanjutan. Kurang berkelanjutannya dimensi teknologi dikarenakan ketersediaan teknologi masih belum memadai. Adapun adaptasi petani terhadap teknologi masih kurang, dalam menerapkan teknologi petani hanya sebatas menggunakan mesin traktor sehingga untuk pengembangan teknologi lainnya masih sangat terbatas. Menurut Purnomo (2014) rendahnya adaptasi teknologi dikalangan petani disebabkan karena tidak efektifnya kegiatan penyuluhan pertanian.

\section{Dimensi Hukum dan Kelembagaan}

Pada dimensi hukum dan kelembagaan (Gambar 1e) dua atribut dengan sensitivitas tertinggi adalah atribut subsidi $(10,06 \%)$ dan kebijakan perlindungan lahan (4,85\%). Indeks keberlanjutan dimensi hukum dan kelembagaan merupakan indeks terendah diantara dimensi lainnya (29,67\%). Rendahnya dimensi hukum dan kelembaagaan disebabkan karena tidak efektifnya program subsidi dari pemerintah dimana masih banyak petani yang masih belum menerima subsidi. Kebijakan perlindungan lahan yaitu LP2B trnyata masih belum berjalan meskipun sudah ditetapkan sebagai kawasan LP2B menurut Perda Kota Tasikmalaya, namun lahan yang ditentukan masih belum ada dan sebagian besar petani belum mengetahui kebijakan tersebut karena kegiatan sosisalisasi LP2B di Kelurahan Setianagara belum berjalan.

Analisis selanjutnya adalah analisis monte carlo yang berguna untuk melihat pengaruh kesalahan (galat) pada model yang dianalisis. Nilai indeks monte carlo akan dibandingkan dengan indeks keberlanjutan setiap dimensi seperti pada Tabel 5. Berdasarkan hasil analisis monte carlo selisih perbandingan antara indeks MDS dan Monte Carlo secara keseluruhan yaitu sebesar 0,39\%. Nilai tersebut dikatakan baik karena nilai kurang dari 1 yang berarti tingkat kesalahan dan ketidakpastian dari model yang dianalisis kecil sehingga model dikatakan sudah valid atau dengan kata lain memiliki tingkat kepercayaan yang tinggi. Menurut Fauzi dan Anna (2005) kecilnya perbedaan nilai indeks keberlanjutan hasil analisis kedua metode 
tersebut mengindikasikan bahwa: (1) iterasi (pengulangan) stabil,

Relatif kecilnya ragam pemberian skor, Kesalahan pemasukan data serta data (2) Kesalahan dalam pemberian skor yang hilang dapat dihindari.

setiap atribut relatif kecil, (3) Proses

Tabel 4. Hasil Analisis Leaverage

\begin{tabular}{|c|c|c|}
\hline Atribut & Dimensi & Nilai RMS (\%) \\
\hline Rasa sayang terhadap lahan & \multirow{6}{*}{ Dimensi Sosial } & 6.53 \\
\hline Regenerasi Petani & & 4.43 \\
\hline Akses penyuluhan & & 3.87 \\
\hline Budaya gotong royong & & 3.86 \\
\hline Partisipasi keluarga dalam usahatani & & 3.78 \\
\hline Tingkat pendidikan petani & & 3.73 \\
\hline Permodalan usahatani & \multirow{6}{*}{ Dimensi Ekonomi } & 4.56 \\
\hline Akses lembaga keuangan & & 3.72 \\
\hline Mekanisme bagi hasil & & 3.42 \\
\hline Kepemilikan peralatan usahatani & & 3.39 \\
\hline Stabilitas harga gabah & & 2.13 \\
\hline Keuntungan usahatani padi & & 2.06 \\
\hline Penggunaan benih lokal dan bersertifikat & \multirow{6}{*}{ Dimensi Lingkungan } & 8.16 \\
\hline Penggunaan pestisida nabati & & 5.64 \\
\hline Pemanfaatan limbah sawah untuk pupuk organik & & 4.52 \\
\hline Penggunaan pupuk organik & & 3.47 \\
\hline Pola tanam & & 2.44 \\
\hline Akses terhadap pengairan & & 2.38 \\
\hline Ketersediaan teknologi tepat guna & \multirow{4}{*}{ Dimensi Teknologi } & 5.47 \\
\hline Adaptasi teknologi & & 3.16 \\
\hline Respon petani terhadap teknologi baru & & 3.06 \\
\hline Kesesuaian teknologi dengan kemampuan petani & & 2.62 \\
\hline Subsidi pemerintah & \multirow{6}{*}{$\begin{array}{l}\text { Dimensi Hukum dan } \\
\text { Kelembagaan }\end{array}$} & 10.06 \\
\hline Kebijakan perlindungan lahan & & 4.85 \\
\hline Keberlanjutan kelompok tani & & 4.69 \\
\hline Penegakan hukum & & 4.69 \\
\hline Sosialisasi LP2B & & 4.63 \\
\hline Akses lembaga keuangan & & 3.72 \\
\hline
\end{tabular}

Tabel 5 Perbandingan Indeks MDS dan Monte Carlo

\begin{tabular}{lccc}
\hline \multicolumn{1}{c}{ Dimensi } & MDS (\%) & Monte Carlo (\%) & Selisih \\
\hline Sosial & 37.68 & 38.03 & 0,35 \\
Ekonomi & 48.37 & 48.22 & 0,15 \\
Lingkungan & 41.00 & 41.42 & 0,42 \\
Teknologi & 36.74 & 37.25 & 0,51 \\
Hukum dan kelembagaan & 29.67 & 30.5 & 0,83 \\
Multidimensi & 38.69 & 39.08 & 0,39 \\
\hline
\end{tabular}

Sumber: Hasil analisis data (2019)

\section{KESIMPULAN DAN SARAN}

Berdasarkan hasil penelitian dan pembahasan, tingkat keberlanjutan kelima dimensi (sosial, ekonomi, lingkungan, teknologi, serta hukum dan kelembagaan) seluruhnya termasuk dalam kategori kurang berkelanjutan. Indeks keberlanjutan lahan sawah secara 
multidimensi sebesar $38,69 \%$ dimana termasuk dalam kategori kurang berkelanjutan. Faktor-faktor atau atributatribut sensitif yang paling mempengaruhi tingkat keberlanjutan lahan sawah secara multidimensi yaitu subsidi pemerintah $(10,06 \%)$, penggunaan benih lokal bersertifikat $(8,16 \%)$, dan rasa sayang terhadap lahan $(6,53 \%)$.

Berdasarkan hasil analisis RAPPaddyField menunjukan lemahnya keberlanjutan dimensi hukum dan kelembagaan dengan indeks terendah sebesar 29,67\%. Hal ini mencerminkan perlunya perhatian yang lebih dalam penegakan hukum serta perbaikan kelembagaan pertanian sehingga saran dalam penelitian ini yaitu :

Merealisasikan kebijakan perlindungan lahan LP2B yang telah ditetapkan melalui Perda Kota Tasikmalaya, (2) Agar kebijakan LP2B dapat berjalan, hendaknya dilakukan pengkajian ulang mengenai sistem intensif dan disintensif serta memperhatikan beberapa aspek yang tercermin dari atribut sensitif yang dalam penelitian ini yaitu; subsidi, penggunaan benih lokal bersertifikat, dan rasa sayang terhadap lahan.

\section{UCAPAN TERIMAKASIH}

Penulis menyampaikan ucapan terimakasih kepada seluruh dosen dan staf Fakultas Pertanian Universitas Padjadjaran, Ir.H. Dede Sudrajat, M.P yang telah membantu selama proses penelitian di lapangan, serta seluruh pihak yang terlibat dalam proses penulisan.

\section{DAFTAR PUSTAKA}

Alder, J., T.J. Pitcher, D. Preikshot, K. Kaschner, dan B. Ferriss. 2000. How Good Is Good?: A Rapid Appraisal Technique For Evaluation of The Sustainability Status of Fisheries of The North Atlantic. Sea Around Us Methodology Review: 136-182.

BPS.2017. Provinsi Jawa Barat dalam angka 2011-2016 . Jawa Barat: Badan Pusat Statistik Jawa Barat..

Fauzi, A., dan S, Anna. 2002. Evaluasi Status Keberlanjutan Pembangunan Perikanan: Aplikasi Pendekatan Rapfish (Studi Kasus Perairan Pesisir DKI Jakarta). Jurnal Pesisir dan Lautan. Vol 4 : (3)

Fauzi, A., dan S, Anna.2005. Pemodelan Sumberdaya Perikanan dan Kelautan untuk Analisis Kebijakan. Jakarta: Gramedia Pustaka.

Kavanagh, P. 2001. Rapid Appraisal of Fisheries (Rapfish) Project.Rapfish Software Description (for Microsof Exel). Fisheries Centre, University of British Columbia. Vancouver, BC, Canada..

Perda Kota Tasikmalaya Nomor 4 Tahun 2012 paragraf 7 Pasal 49 Ayat 2 RTRW Tahun 2011-2031.

Rasmikayati, E., Sulistyowati, L., \& Saefudin, B. R. 2017. Risiko 
Produksi Dan Pemasaran Terhadap Pendapatan Petani Mangga: Kelompok Mana Yang Paling Berisiko. Mimbar Agribisnis 3(2), 105-116.

Swastika, D.K.S., J. Wargiono, Soejitno, dan A. Hasanuddin. 2007. AnalisisKebijakan Peningkatan Produksi Padi Melalui Efisiensi Pemanfaatan Lahan Sawah di Indonesia. Analisis Kebijakan Pertanian. Vol (1): 3652.

U. U. R. I. 41. Tahun 2009 Tentang Perlindungan Pertanian Pangan
Berkelanjutan. Departemen

Pertanian, Direktorat Jenderal Pengelolaan Lahan dan Air. Provinsi Jawa Barat Dalam Angka 2011-2015.

Widiatmaka, K. Munibah, dan I. Firmansyah. 2015. Appraisal Keberlanjutan Multidimensi Penggunaan Lahan Untuk Sawah di Karawang Jawa Barat. Jurnal KAWISTARA Vol (2): 99 220 